\title{
Olefins from Biomass Intermediates: A Review
}

\author{
Vasiliki Zacharopoulou ${ }^{1}$ and Angeliki A. Lemonidou ${ }^{1,2, *}$ \\ 1 Department of Chemical Engineering, Aristotle University of Thessaloniki, University Campus, \\ 54124 Thessaloniki, Greece; vzacharopoulou@auth.gr \\ 2 Chemical Process Engineering Research Institute (CERTH/CPERI), P.O. Box 60361 Thermi, \\ 57001 Thessaloniki, Greece \\ * Correspondence: alemonidou@cheng.auth.gr; Tel.: +30-2310-996-273
}

Received: 16 November 2017; Accepted: 19 December 2017; Published: 23 December 2017

\begin{abstract}
Over the last decade, increasing demand for olefins and their valuable products has prompted research on novel processes and technologies for their selective production. As olefins are predominately dependent on fossil resources, their production is limited by the finite reserves and the associated economic and environmental concerns. The need for alternative routes for olefin production is imperative in order to meet the exceedingly high demand, worldwide. Biomass is considered a promising alternative feedstock that can be converted into the valuable olefins, among other chemicals and fuels. Through processes such as fermentation, gasification, cracking and deoxygenation, biomass derivatives can be effectively converted into $C_{2}-C_{4}$ olefins. This short review focuses on the conversion of biomass-derived oxygenates into the most valuable olefins, e.g., ethylene, propylene, and butadiene.
\end{abstract}

Keywords: olefins; biomass; ethylene; propylene; butadiene; catalysis

\section{Introduction}

The importance of $\mathrm{C}_{2}-\mathrm{C}_{4}$ olefins (i.e., $\mathrm{C}_{2} \mathrm{H}_{4}, \mathrm{C}_{3} \mathrm{H}_{6}$, butenes, and $\mathrm{C}_{4} \mathrm{H}_{6}$ ) has been highlighted because of their numerous applications as key building blocks in the chemical industry, linked with the increasing needs of the expanding global population [1]. These lower olefins are the most prevalent organic compounds, with the highest production volumes, worldwide, highly dependent on crude oil and natural gas products [2]. It is estimated that 400 million tons of olefins are annually produced, using one billion tons as hydrocarbon feedstock, via processes such as fluid-catalytic cracking, steam cracking, and dehydrogenation [3]. Almost $60 \%$ of the global feedstocks are used in FCC units, and approximately $40 \%$ in steam cracking processes. (Figure 1) Produced olefins can be used in a wide spectrum of high-end applications such as packaging, construction, solvents, coatings, and synthetic fibers [4].

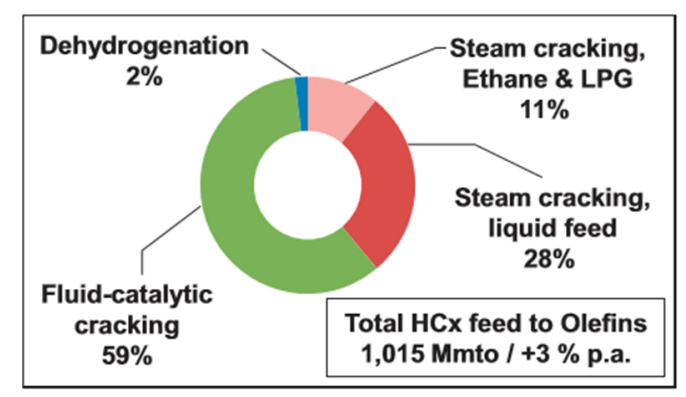

Figure 1. Olefin production methods using hydrocarbon feedstocks. Reproduced from [3]. 2014, WILEY-VCH Verlag GmbH \& Co. 
$\mathrm{C}_{2} \mathrm{H}_{4}$ constitutes the most predominant olefin in the global market and is primarily produced via naphtha steam cracking, among various hydrocarbon feedstocks, as well as through ethane thermal cracking. Globally, $57 \%$ (Figure 2) of the $\mathrm{C}_{2} \mathrm{H}_{4}$ volume is produced via naphtha and gas oil steam cracking and 38\% through ethane and LPG (Liquefied Petroleum Gas) steam cracking. Naphtha is a liquid fraction obtained from petroleum refining processes, such as catalytic cracking and hydrocracking. Depending on its origin, it contains variable amounts of paraffins, aromatic, and olefinic compounds. The ratio of these components can indicate the process that the specific fraction can be used for the optimum results. At high temperatures (i.e., $650-750{ }^{\circ} \mathrm{C}$ ), naphtha and gas oil can yield 30 and 25 wt. $\%$ of $\mathrm{C}_{2} \mathrm{H}_{4}$, respectively. In the case of ethane, added along with naphtha in the feed stream, yields of $\mathrm{C}_{2} \mathrm{H}_{4}$ can reach $80 \mathrm{wt}$. \% [5]. Its eminent industrial uses cause the world demand for $\mathrm{C}_{2} \mathrm{H}_{4}$ to incessantly increase, as it can be used for significant applications, such as the production of intermediate chemicals, mainly in the industry of plastics. i.e., polymers (e.g., poly-ethylene), propionaldehyde - via hydroformylation, vinyl chloride - via halogenation and de-hydrohalogenation, alpha-olefins-via oligomerization, and $\mathrm{C}_{2} \mathrm{H}_{4}$ oxide and acetaldehyde-via oxidation $[4,6,7]$. In recent years, bio-ethanol has been extensively studied as an alternate feedstock for $\mathrm{C}_{2} \mathrm{H}_{4}$ production [8]. Other bio-derived compounds such as methanol and dimethyl-ether, can also be used as a feedstock for $\mathrm{C}_{2} \mathrm{H}_{4}$, via Methanol to Olefins (MTO) and Dimethyl-ether to Olefins (DMTO) processes [9,10]. Bio-ethylene can also be produced via bio-synthesis from various enzymes or microorganisms [11].

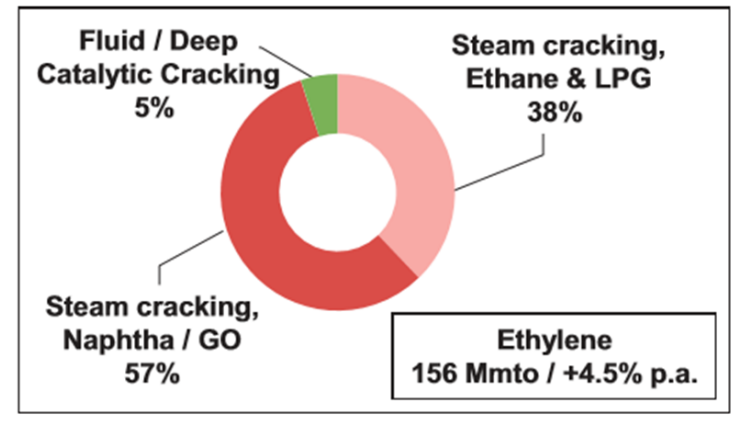

Figure 2. $\mathrm{C}_{2} \mathrm{H}_{4}$ production methods using hydrocarbon feedstocks. Reproduced from [3]. 2014, WILEY-VCH Verlag GmbH \& Co.

$\mathrm{C}_{3} \mathrm{H}_{6}$ is the second most significant olefin, conventionally produced via steam cracking, as a co-product, or through fluid catalytic cracking (FCC). (Figure 3) $\mathrm{C}_{2} \mathrm{H}_{4}$ and gasoline production severely affect $\mathrm{C}_{3} \mathrm{H}_{6}$ production; recently, steam crackers switch to ethane feedstocks, suppressing concurrent production of $\mathrm{C}_{3} \mathrm{H}_{6}$, while its demand outpaces existing steam and fluid catalytic cracking capacity [12]. $\mathrm{C}_{3} \mathrm{H}_{6}$ is mainly used for the production of polypropylene, as well as for the synthesis of numerous platform chemicals (e.g., cumene, acrylonitrile, propylene-oxide) [13]. The importance of $\mathrm{C}_{3} \mathrm{H}_{6}$ in the $\mathrm{C}_{3}$ value chain addresses the need for alternative processes; using the conventional technology, $\mathrm{C}_{3} \mathrm{H}_{6}$ can also be produced through $\mathrm{C}_{4}-\mathrm{C}_{8}$ olefin cracking, or through FCC under severe conditions in order to increase produced volume [12]. On-purpose production methods that include propane dehydrogenation (PDH) [14], olefin metathesis [15], or methanol to olefins (MTO) [16,17], have recently been implemented, as well as using other unconventional feedstocks [18], such as bio-alcohols and vegetable oils. 


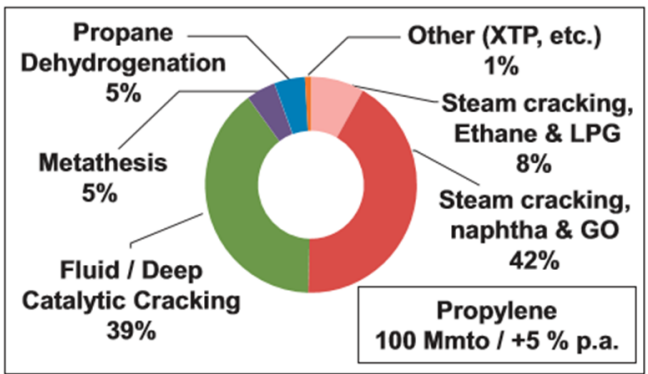

Figure 3. $\mathrm{C}_{3} \mathrm{H}_{6}$ production methods using hydrocarbon feedstocks. Reproduced from [3]. 2014, WILEY-VCH Verlag GmbH \& Co. ( ${ }^{*}$ XTP refers to propylene production from any kind of feedstock).

$\mathrm{C}_{4}$ olefins are mostly produced via fluid catalytic cracking, as well as through steam cracking (Figure 4). Most common $\mathrm{C}_{4}$ olefins are $\mathrm{C}_{4} \mathrm{H}_{6}$, isobutylene, and butenes; $\mathrm{C}_{4} \mathrm{H}_{6}$ is a key chemical, currently used for the production of polymers (i.e., rubbers), butylenes are expended in the fuel industry for the production of blending components and octane enhancers, and n-butenes are used as co-monomers of polyethylene and for the synthesis of higher olefins. $\mathrm{C}_{4} \mathrm{H}_{6}$ is the prevalent $\mathrm{C}_{4}$ olefin, conventionally co-produced via naphtha and gas oil cracking, along with $\mathrm{C}_{3} \mathrm{H}_{6}$ and $\mathrm{C}_{2} \mathrm{H}_{4}$, among others; $\mathrm{C}_{4} \mathrm{H}_{6}$ yield via cracking is substantially low, highlighting the need for more targeted production methods [4]. Demand for $\mathrm{C}_{4} \mathrm{H}_{6}$ is expected to increase, as it can be used as a bio-based feedstock for greener rubbers. Several bio-based routes have based proposed for $\mathrm{C}_{4} \mathrm{H}_{6}$ - production; bio-ethanol constitutes the most promising feedstock for this purpose.

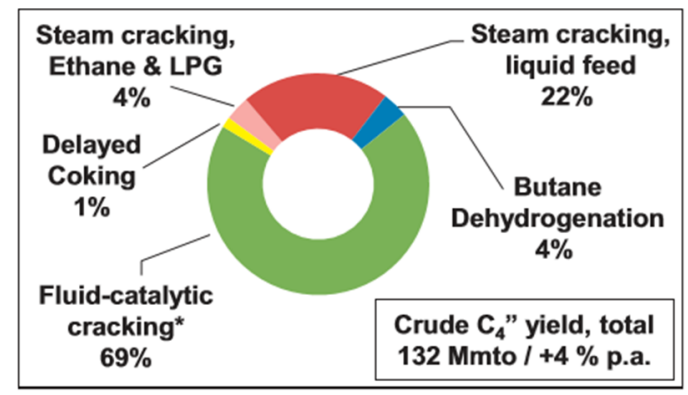

Figure 4. $C_{4}$ olefin production methods using hydrocarbon feedstocks. Reproduced from [3]. 2014, WILEY-VCH Verlag GmbH \& Co.

Overall, existing olefin production is highly dependent on fossil resources that are expended into energy-consuming processes, heavily contributing to the environmental affliction. Continuously increasing demand has turned the petrochemical industry towards optimization of existing processes in order to meet challenging capacities, while lowering the vast production costs. Recently, investigation of alternative feedstocks has been considerably studied in order to offer an attractive solution untrammeled from the limited crude oil reserves; coal, natural gas, and biomass are some of the examples [2,4]. Coal has been used in coal-rich countries as a feedstock for chemicals' production; even though it reduces dependence on fossil resources, the resulting $\mathrm{CO}_{2}$ emissions limit the extent of its applications [4]. Methane prices have recently dropped due to technological advances, enabling the use of shale gas as an attractive, economical feedstock. Thus, cost-effective olefin production, via steam cracking, has been enabled, already implemented in the olefin market, primarily for the production of $\mathrm{C}_{3} \mathrm{H}_{6}$ and higher olefins $[12,19,20]$. Renewable feedstocks offer great advantages in terms of sustainability, energy consumption, environmental pollution, $\mathrm{CO}_{2}$ emissions, and cost; biomass is an abundant carbon-source with potential to replace fossil resources [21]. Through processes such as fermentation, hydro-deoxygenation or gasification, light olefins can be produced from bio-feedstocks, 
or from bio-intermediates (e.g., ethanol, butanol, naphtha, methanol, and propane) via dehydration, metathesis, and steam-cracking, among others [22].

In this context, the alternative production of olefins from biomass intermediates is reviewed and compared to the conventional processes, with emphasis on the most promising chemical technologies for future applications that progress biomass valorization.

\section{Olefins from Biomass}

Following the incessantly increasing demand worldwide, technological advances have enabled the production of light olefins from various biomass-derived feedstocks, obtaining mainly mixtures of $\mathrm{C}_{2}-\mathrm{C}_{4}$ olefins. Specific processes can be selective to the production of a certain product, as will be discussed in this chapter. Overall, olefins from biomass are predominantly produced from biomass intermediates, and more specifically, from alcohols, diols, and other oxygenates. These intermediates are, in most cases, formed via fermentation, hydro-deoxygenation, or gasification processes (Figure 5).

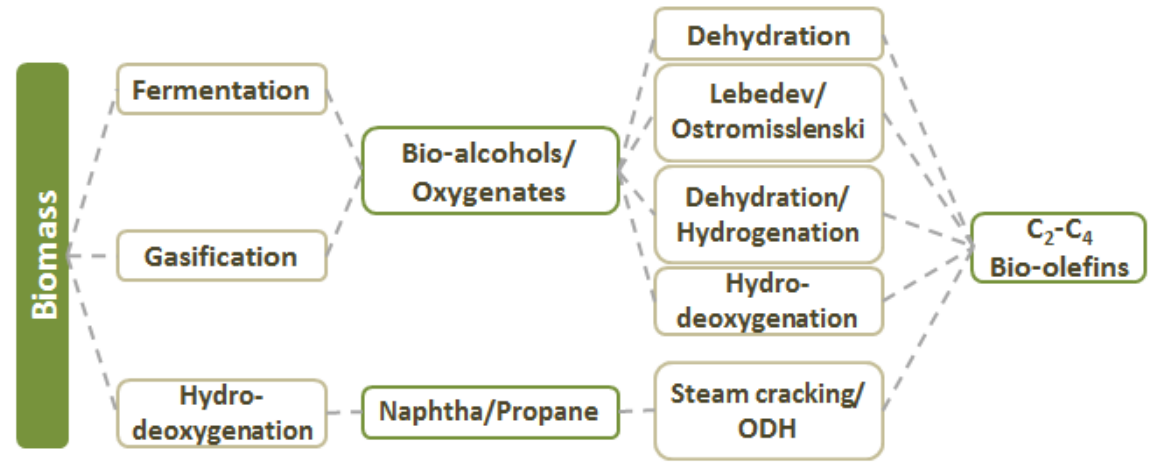

Figure 5. Biomass to olefins primary routes.

\subsection{Ethylene $\left(\mathrm{C}_{2} \mathrm{H}_{4}\right)$}

As mentioned above, steam cracking (mainly using naphtha as a feedstock) is the most extensively used process for $\mathrm{C}_{2} \mathrm{H}_{4}$ production from hydrocarbons. Steam cracking operating conditions require vast amounts of energy, thus increasing the production cost, and heavily contributing to environmental issues. Even though the installed technology for these processes has already been modified for increased efficiency, novel production methods have been explored in order to reduce production cost and to substitute the finite fossil resources. Apart from $\mathrm{C}_{2} \mathrm{H}_{4}$ conventional production from petrochemicals, $\mathrm{C}_{2} \mathrm{H}_{4}$ can be effectively produced from renewable feedstocks, such as plants, microorganisms, and bio-alcohols (Figure 6).

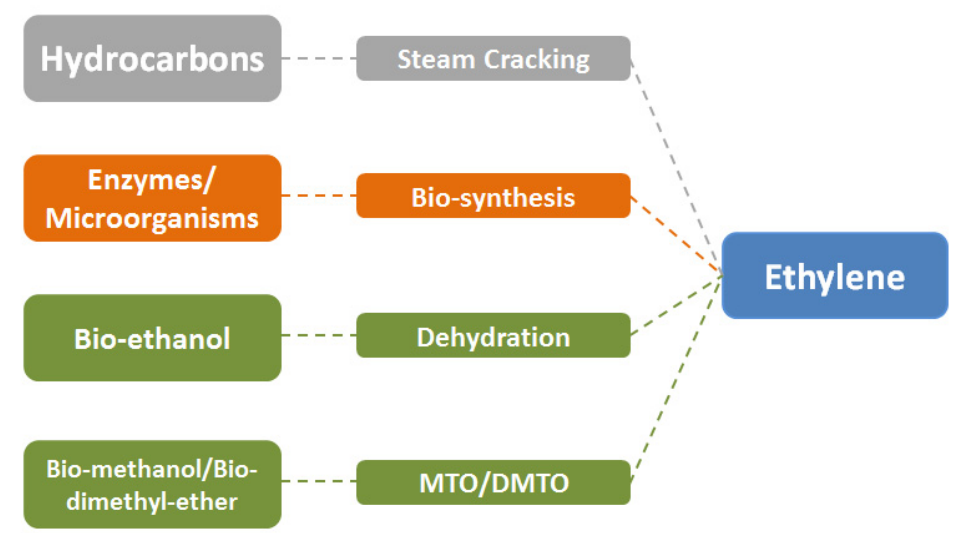

Figure 6. Schematic chart of $\mathrm{C}_{2} \mathrm{H}_{4}$ production methods. 
$\mathrm{C}_{2} \mathrm{H}_{4}$ biosynthesis is a natural pathway, as it constitutes an important hormone that plants recognize and produce [11]. ACC synthase and oxidase are two vital enzymes that enable $\mathrm{C}_{2} \mathrm{H}_{4}$ production from ACC (1-aminocyclopropane-1carboxylic acid) and SAM (S-adenosyl methionine), along with carbon dioxide and $\mathrm{HCN}$, via the Yang cycle, starting from methionine via three consecutive reaction steps: (a) methionine is converted into SAM by SAM synthetase; (b) ACC synthetase converts SAM to ACC; and finally, (c) ACC is converted into $\mathrm{C}_{2} \mathrm{H}_{4}$ by ACC oxidase [23]. (Scheme 1) Microorganisms, such as bacteria and fungi have also been reported to produce $\mathrm{C}_{2} \mathrm{H}_{4}$ starting from methionine via the KMBA (2-keto-4-methylthiobutyric acid) formation pathway or through 2-oxoglutarate conversion [24-26]. Ethylene production rate can reach $2859.2 \mu \mathrm{mol} / \mathrm{gCDW} / \mathrm{h}$ (CDW-Cell Dry Weight) from Pseudomonas putida [27]. Despite the fact that bio-synthesis technology is at its early stages, recent techno-economic analyses highlight the potential of these processes for on-purpose $\mathrm{C}_{2} \mathrm{H}_{4}$ production. However, further studies are required in order to reduce cost and overcome or improve aspects such as productivity and product separation. Advances in the biotechnological processes could improve productivity and reduce cost, enabling future development of $\mathrm{C}_{2} \mathrm{H}_{4}$ biosynthesis methods [28].

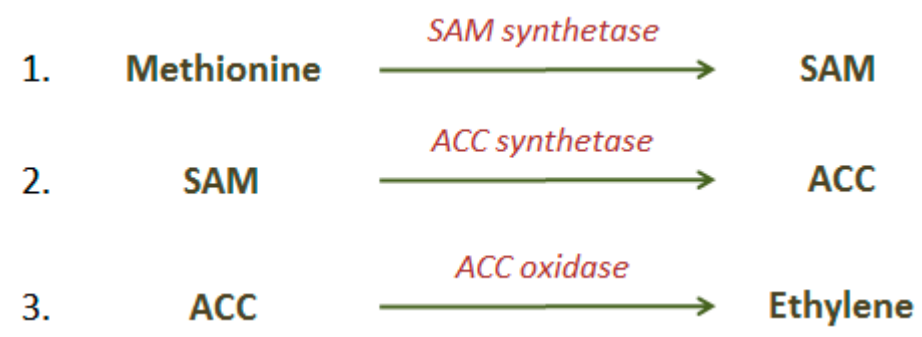

Scheme 1. Steps for $\mathrm{C}_{2} \mathrm{H}_{4}$ bio-synthesis.

Ethanol, derived from biomass, i.e., cellulose, corn, and sugarcane [8] is the most common bio-feedstock for the production of $\mathrm{C}_{2} \mathrm{H}_{4}$. Several companies worldwide, such as Braskem (Sao Paulo, Brazil), Axens (Rueil-Malmaison, France), Solvay (Brussels, Belgium), and BP (London, United Kingdom), focus on research and plant operation for ethanol dehydration into $\mathrm{C}_{2} \mathrm{H}_{4}$ [13-15], as the global demand for $\mathrm{C}_{2} \mathrm{H}_{4}$ is continuously increasing [29,30]. Even though each company has developed and installed specific technologies for this reaction, ethanol dehydration typically includes two steps; reaction of ethanol dehydration and purification of products [29]. Bio-ethanol can be produced via fermentation processes causing sugars to selectively break down into ethanol, at high rates, with limited by-product formation [31]. However, the strong dependence on sugar production costs limit their application [30,32]. More complex feedstocks with higher market availability and thus lower cost (i.e., cellulose, hemicellulose, and lignocellulose) are more attractive but their direct conversion into ethanol is challenging and has not been reported to be satisfactorily viable for applications in the industry [33].

Bio-ethanol dehydration is an endothermic reaction, requiring relatively moderate temperatures (i.e., $180-500{ }^{\circ} \mathrm{C}$ ) and the presence of a catalyst. The mechanism of bio-ethanol dehydration consists of the following steps: (a) protonation of the hydroxyl group by an acid catalyst, (b) deprotonation of the methyl group by the conjugate base of the catalyst, and (c) rearrangement to form $\mathrm{C}_{2} \mathrm{H}_{4}$ (Scheme 2) [30]. The selection of the most suitable catalyst for bio-ethanol dehydration into $\mathrm{C}_{2} \mathrm{H}_{4}$ is of key importance, in order to lower reaction temperature and overcome common issues, such as catalyst deactivation due to coke formation, particle collision, and agglomeration [29,30]. Acid catalysts, such as zeolites and silicoaluminophosphates (SAPO), have been widely used for this reaction, over the last decades, as they promote selective conversion into the desired product, with extremely high conversion and selectivity values, despite the fact that catalysts need to be frequently regenerated $[30,34]$. Actually, SAPO catalysts are significantly active in this reaction, reaching $98.0 \%$ selectivity to ethylene, at $250{ }^{\circ} \mathrm{C}$, over SAPO- $11-4$ and $98.4 \%$, at $340{ }^{\circ} \mathrm{C}$, over Mn-SAPO-34 [35,36]. However, over modified HZSM-5 
and MCM-41 catalysts, selectivity to $\mathrm{C}_{2} \mathrm{H}_{4}$ is even higher (i.e., 99.0\%) [37]. Moreover, alumina-based catalysts, such as $\mathrm{Al}_{2} \mathrm{O}_{3}-\mathrm{MgO} / \mathrm{SiO}_{2}$, exhibited high conversion and selectivity values (i.e., 99.0 and $97.0 \%$, respectively) requiring regeneration over longer periods of operation [29]. Tungsten-based heteropolyacids, supported on various substances are highly selective at relatively low reaction temperatures (i.e., $180-250{ }^{\circ} \mathrm{C}$ ) [38]. It has been proven that acid-base sites on the catalyst surface are linked with the product distribution of this reaction; ethanol dehydration most probably proceeds via the formation of intermediate species and highly depends on temperature, ethanol partial pressure, and the nature of acid-base sites [30,39-43]. In fact, as ethanol dehydration is an endothermic reaction, the reaction temperature strongly affects $\mathrm{C}_{2} \mathrm{H}_{4}$ yield. Basic catalysts, such as $\mathrm{MgO}$ or $\mathrm{CaO}$ have also been used with results that resembled those, over acidic catalysts. Phosphoric acid, oxides, molecular sieves, and other heteropoly acid catalysts can also be used for this purpose [29]. Syndol is a commercial catalyst, used by Halcon SD (USA), to obtain high ethanol conversion and selectivity to ethylene, at $400-500{ }^{\circ} \mathrm{C}[29,44-46]$. Overall, a selection of the most promising catalysts for ethanol conversion into $\mathrm{C}_{2} \mathrm{H}_{4}$ are presented in Table 1 .

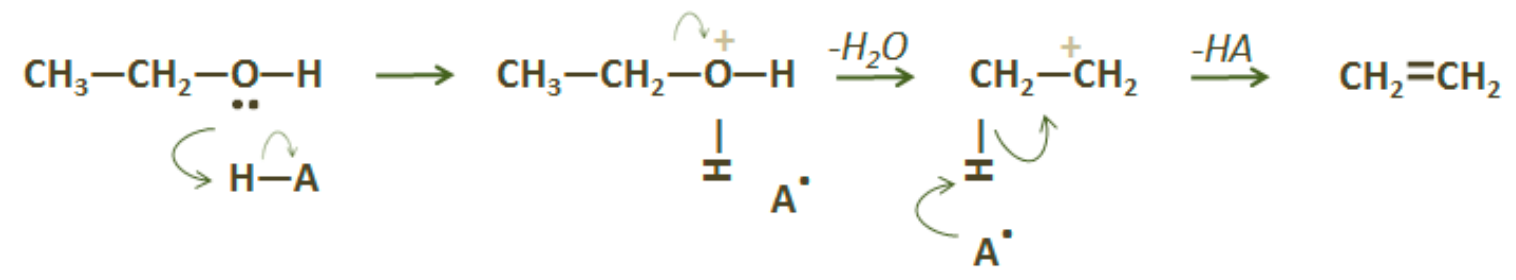

Scheme 2. Mechanism of bio-ethanol dehydration to $\mathrm{C}_{2} \mathrm{H}_{4}$.

Table 1. Selected catalysts for bio-ethanol dehydration to $\mathrm{C}_{2} \mathrm{H}_{4}$.

\begin{tabular}{|c|c|c|c|c|c|}
\hline Catalyst & $\begin{array}{c}\text { Ethanol } \\
\text { Conversion (\%) }\end{array}$ & $\begin{array}{c}\text { Selectivity to } \\
\mathrm{C}_{2} \mathrm{H}_{4}(\%)\end{array}$ & Temperature $\left({ }^{\circ} \mathrm{C}\right)$ & WHSV $^{a} /$ LHSV $^{b}\left(h^{-1}\right)$ & Reference \\
\hline Mn-SAPO-34 & 99.4 & 98.4 & 340 & $2.0^{\mathrm{a}}$ & [35] \\
\hline $0.5 \%$ La-2\%P-HZSM- 5 & 100.0 & 99.9 & $240-280$ & $2.0^{\mathrm{a}}$ & [47] \\
\hline TPA-MCM-41 * & 98.0 & 99.9 & 300 & $2.9^{\mathrm{a}}$ & [48] \\
\hline SynDol ${ }^{* *}$ & 99.0 & 96.8 & 450 & $26-234^{b}$ & {$[29,44-46]$} \\
\hline STA-MCM- $41^{* * *}$ & 99.0 & 99.9 & 250 & $2.9^{\mathrm{a}}$ & [49] \\
\hline
\end{tabular}

${ }^{*}$ tungstophosphoric acid (TPA), ${ }^{* *} \mathrm{MgO}-\mathrm{Al}_{2} \mathrm{O}_{3} / \mathrm{SiO}_{2},{ }^{* * *}$ silicotungstic acid (STA). ${ }^{a}$ Weight hourly space velocity (WHSV), biquid hourly space velocity (LHSV).

Methanol is another alcohol that can be converted into olefins, through the well-known methanol-to-olefins (MTO) process. The MTO reaction is one of the most important processes for producing olefins from a $C_{1}$ feedstock [50]. MTO was initially proposed, in 1977, by Mobil Corporation [51], followed by numerous research studies, focusing on the development of a commercially available technology $[17,52]$. Within this context, the first MTO plant was installed in 2010, in China, for the production of light olefins from coal [53].

Bio-methanol can be produced via several processes including pyrolysis, bio-synthesis, gasification, and electrolysis, using a wide range of biomass waste, such as agricultural, forest, and municipal [17,53-55]. Although most of these processes are currently under development, the installation of bio-methanol production units requires further studies on design and energy efficiency in order to ensure feasibility of large-scale application [56].

MTO is an autocatalytic reaction that conventionally takes place at moderate temperature (i.e., $300-450{ }^{\circ} \mathrm{C}$ ), over acidic catalysts. A number of suggestions on the mechanism of MTO has been proposed, showing that most conclusions agree that the reaction network consists of at least three main pathways: (a) direct methanol conversion; (b) direct conversion of ethylene; and (c) ethane methylation by methanol [52]. Depending on the catalyst used, MTO can selectively yield mainly $\mathrm{C}_{2} \mathrm{H}_{4}$ and $\mathrm{C}_{3} \mathrm{H}_{6}$; most studies focus on methanol conversion into ethylene, as the main product. (Scheme 3) 
Over SAPO catalysts and zeolites, bio-methanol can be selectively converted into light olefins; over SAPO-34, selectivity to $\mathrm{C}_{2} \mathrm{H}_{4}$ and $\mathrm{C}_{3} \mathrm{H}_{6}$ is $60.0 \%$, at $350-425^{\circ} \mathrm{C}$ [57]. Modification on the catalyst synthesis procedure strongly affects product distribution. Dimethyl ether-to-olefins (DMTO) is a similar process that yields the same products. Bio-dimethyl ether can be produced from lignocellulosic biomass, via pyrolysis and gasification, resulting in the formation of olefins (i.e., $\mathrm{C}_{2} \mathrm{H}_{4}$ and $\mathrm{C}_{3} \mathrm{H}_{6}$ ) and syngas, following the bioliq ${ }^{\circledR}$ concept developed in Karlsruhe Institute of Technology, which is already implemented in a large scale unit in Germany [58-60]. DMTO can take place at high temperature (i.e., $723{ }^{\circ} \mathrm{C}$ ) and low pressure (i.e., 4 bar), fully converting dimethyl ether (DME) into $\mathrm{C}_{2} \mathrm{H}_{4}(45.0 \%)$, $\mathrm{C}_{3} \mathrm{H}_{6}(39.0 \%)$, butenes $(8.0 \%)$, and other light gases [10]. DME to olefins conversion is driven by a substantially complex reaction mechanism based on methylation, oligomerization, and hydrocarbon formation and cracking reactions, over zeolite catalysts [61].

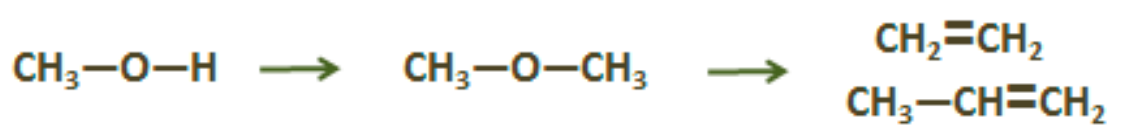

Scheme 3. Bio-methanol conversion into olefins (MTO).

An overall comparison of the main $\mathrm{C}_{2} \mathrm{H}_{4}$ production processes is shown in Table 2. Despite of the technological advances of the last decades, bio-ethylene production processes cannot replace those dependent on fossil resources. As bio-synthesis processes are a recent research subject, further studies on the reduction of the cost and on increasing the productivity are essential prior to considering their industrial application. Bio-ethanol dehydration is the most promising alternative for the production of "green" $\mathrm{C}_{2} \mathrm{H}_{4}$, as numerous studies have focused on the selection of the most suitable catalyst, lowering the reaction temperature, while increasing the yield to $\mathrm{C}_{2} \mathrm{H}_{4}$. As ethanol dehydration has already been implemented, the only set-back for industrial bio-ethanol dehydration to $\mathrm{C}_{2} \mathrm{H}_{4}$ is the production and availability of bio-ethanol. MTO and DMTO processes have also been extensively studied with encouraging results regarding their commercial applications. Likewise, bio-methanol and bio-DME production is also limited, lowering prospect productivity. However, future increases of the produced bio-feedstocks could eliminate this issue, achieving high yields, in cost-competitive processes, as steam-cracking units. Future studies should focus on cost reduction linked with the implementation of the bio-based methods.

Table 2. Comparison of $\mathrm{C}_{2} \mathrm{H}_{4}$ production processes.

\begin{tabular}{|c|c|c|c|c|c|}
\hline Process & Steam Cracking & Bio-Synthesis & $\begin{array}{l}\text { Bio-Ethanol } \\
\text { Dehydration }\end{array}$ & МTO & DMTO \\
\hline Feedstock & HC (Naphtha) & ACC/SAM & Bio-ethanol & Bio-methanol & Bio-DME \\
\hline $\begin{array}{l}\text { Operating } \\
\text { Conditions }\end{array}$ & $\begin{array}{c}675-700{ }^{\circ} \mathrm{C} \text { atmospheric } \\
\text { pressure }\end{array}$ & $\begin{array}{l}\text { Ambient, aerobic } \\
\text { conditions }\end{array}$ & $180-500{ }^{\circ} \mathrm{C}$ & $\begin{array}{l}300-500{ }^{\circ} \mathrm{C} \\
\text { low pressure }\end{array}$ & $\begin{array}{l}675-750{ }^{\circ} \mathrm{C}, \\
\text { low pressure }\end{array}$ \\
\hline Advantages & $\begin{array}{l}\text { Already installed } \\
\text { technology }\end{array}$ & $\begin{array}{l}\text { Selective sustainable } \\
\text { production }\end{array}$ & $\begin{array}{l}\text { Commercial } \\
\text { application }\end{array}$ & \multicolumn{2}{|c|}{ Close to commercial application } \\
\hline Disadvantages & $\begin{array}{c}\text { Energy intense, } \\
\text { environmental concerns, } \\
\text { finite resources }\end{array}$ & $\begin{array}{l}\text { Increased cost, low } \\
\text { productivity }\end{array}$ & $\begin{array}{l}\text { Limited } \\
\text { bio-ethanol } \\
\text { supply }\end{array}$ & \multicolumn{2}{|c|}{$\begin{array}{l}\text { Limited production of } \\
\text { bio-feedstocks }\end{array}$} \\
\hline Yield to $\mathrm{C}_{2} \mathrm{H}_{4}$ & $31.3 \%$ & - & $99.9 \%$ & $41.5 \%$ & $45.0 \%$ \\
\hline
\end{tabular}

\subsection{Propylene $\left(\mathrm{C}_{3} \mathrm{H}_{6}\right)$}

As the demand for $\mathrm{C}_{3} \mathrm{H}_{6}$ increases, research focuses on on-purpose production of $\mathrm{C}_{3} \mathrm{H}_{6}$, based on biomass resources, aiming at substituting oil-based feedstocks, in more environmentally friendly processes. Corn, vegetable oils and other biomass products have been effectively used as feedstocks for the production of bio-propylene, via processes such as gasification, metathesis, dehydrogenation, fermentation, and cracking [22]. 
Conventionally, $\mathrm{C}_{3} \mathrm{H}_{6}$ is a by-product of $\mathrm{C}_{2} \mathrm{H}_{4}$ production via steam cracking of hydrocarbons and FCC of gas oil. (Figure 7) At high temperatures, various hydrocarbons (e.g., naphtha, ethane, and propane) are co-fed, under the most suitable operating conditions, to selectively yield $\mathrm{C}_{3} \mathrm{H}_{6}$ [62]. FCC, also uses hydrocarbons to produce $\mathrm{C}_{3} \mathrm{H}_{6}$, at moderate pressure and high temperatures, over zeolites, such as, ZSM-5, often modified with metals to increase selectivity to $\mathrm{C}_{3} \mathrm{H}_{6}$ [63]. It is considered greener than steam cracking due to lower energy demand and decreased $\mathrm{CO}_{2}$ emissions. Apart from the well-known steam cracking and FCC, olefin metathesis and methanol to $\mathrm{C}_{3} \mathrm{H}_{6}$ are also considered alternatives for industrial application. Moreover, alkanes can be converted into alkenes via catalytic dehydrogenation; propane can be used as a feedstock, at high temperature and atmospheric pressure. Propane dehydrogenation plants have already been installed worldwide by several companies; Linde/BASF (Alabama, USA), Lummus Technology (New Jersey, USA), Snamprogetti/Yarsintez (Jubail, Saudi Arabia), UOP (Illinois, USA), etc., mostly using chromium, and Pt-Sn catalysts [64]. Methanol to $\mathrm{C}_{3} \mathrm{H}_{6}$ is actually included in methanol to olefins reactions, described in the previous chapter; zeolites (i.e., ZSM-5) are the most active catalysts in order to selectively produce $\mathrm{C}_{3} \mathrm{H}_{6}$ from methanol [65].

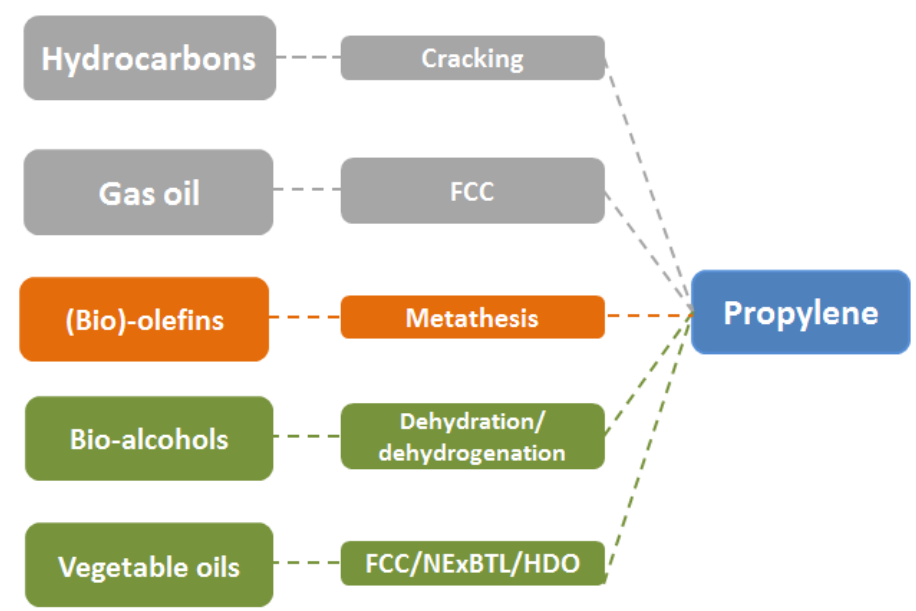

Figure 7. Schematic chart of $\mathrm{C}_{3} \mathrm{H}_{6}$ production methods.

As mentioned above, bio-ethanol can be produced through various methods. Apart from constituting a valuable feedstock for $\mathrm{C}_{2} \mathrm{H}_{4}$ production, bio-ethanol can also be used for $\mathrm{C}_{3} \mathrm{H}_{6}$ production; $\mathrm{C}_{2} \mathrm{H}_{4}$ from bio-ethanol can undergo dimerization followed by the well-known metathesis reaction, along with butenes, thus producing $\mathrm{C}_{3} \mathrm{H}_{6}$ [66]. For this process, not only bio-ethylene can be derived from biomass (i.e., bio-ethanol), but also bio-butylene from bio-butanol dehydration [67]. In fact, butanol can be produced from bio-ethanol, via the Guerbet process, where higher alcohols can be formed, upon condensation of two primary alcohols [68]. For this purpose, basic oxides, such as $\mathrm{MgO}$ and hydrotalcites have been active in ethanol conversion into butanol, reaching $85 \%$ selectivity [69]. N-butanol can also be produced through fermentation; several companies (e.g., Versalis -San Donato Milanese, Italy, Global Bioenergies - Evry, France) have already developed biochemical processes for the production of $\mathrm{C}_{4}$ alcohols. Through the ABE process (Acetone-Butanol-Ethanol), $\mathrm{C}_{4}$ alcohols can be produced via carbohydrate fermentation by genetically modified micro-organisms [39].

The metathesis reaction can yield $\mathrm{C}_{3} \mathrm{H}_{6}$ using $\mathrm{C}_{2} \mathrm{H}_{4}$ and butenes as a feedstock, via two different approaches: (a) dimerization of bio-ethylene and then reaction with remaining bio-ethylene and (b) direct reaction of bio-ethylene and bio-butene. (Scheme 4) $\mathrm{C}_{2} \mathrm{H}_{4}$ dimerization processes have already been implemented in the industry (e.g., AlphaButol by Axens- Rueil-Malmaison, France), operating under relatively mild conditions (i.e., $0-100{ }^{\circ} \mathrm{C}$ ) and over metal catalysts, such as Ti and $\mathrm{Ni}$ [70]. In direct reaction processes, (e.g., Olefin Conversion Technology-OCT ABB Lummus Global), both homogeneous and heterogeneous catalysts have been employed. Heterogeneous (e.g., tungsten, 
molybdenum, or Rhenium oxides, on alumina or silica) are usually preferred over homogeneous, such as organometallic complexes. Tungsten oxides, supported on silica have been used for the OCT process, at temperatures above $260{ }^{\circ} \mathrm{C}$ and $30-35$ bar, reaching more than $90.0 \%$ selectivity to $\mathrm{C}_{3} \mathrm{H}_{6}$, for $60.0 \%$ butene conversion [71]. Pre-reduction treatment, as well as increased acidity obtained using more acidic supports, enhances catalytic activity at lower temperature [72]. Rhenium catalysts have exhibited selectivity $\sim 100 \%$, however fast deactivation requires continuous regeneration [73]. Molybdena catalysts have also been used in the Shell High Olefin Process (SHOP), producing $\alpha$-olefins through the oligomerization of $\mathrm{C}_{2} \mathrm{H}_{4}$, followed by olefin metathesis [74].

$$
2 \mathrm{CH}_{2}=\mathrm{CH}_{2} \longrightarrow \mathrm{CH}_{2}=\mathrm{CH}-\mathrm{CH}_{2}-\mathrm{CH}_{3} \longrightarrow \mathrm{CH}_{3}-\mathrm{CH}=\mathrm{CH}--\mathrm{CH}_{3}
$$

$$
\mathrm{CH}_{3}-\mathrm{CH}=\mathrm{CH}--\mathrm{CH}_{3}+\mathrm{CH}_{2}=\mathrm{CH}_{2} \longrightarrow 2 \mathrm{CH}_{2}=\mathrm{CH}-\mathrm{CH}_{3}
$$

Scheme 4. $\mathrm{C}_{3} \mathrm{H}_{6}$ formation via metathesis.

Solely 1-butene, produced via bio-butanol dehydration, can also be used as a feedstock for $\mathrm{C}_{3} \mathrm{H}_{6}$ formation, as 1-butene is isomerized to 2-butene, and then both react via metathesis to form $\mathrm{C}_{3} \mathrm{H}_{6}$ and 2-pentene [75]. Moreover, oligomerization/cracking of $\mathrm{C}_{2} \mathrm{H}_{4}$ from bio-ethanol can result in $\mathrm{C}_{3} \mathrm{H}_{6}$ production [76-78]. The direct ethanol to $\mathrm{C}_{3} \mathrm{H}_{6}$ process (ETP) has recently been explored, over catalysts such as zeolites [79-81] and metal oxide catalysts [82-84] in order to increase yield to $\mathrm{C}_{3} \mathrm{H}_{6}$ against the most common by-products (i.e., $\mathrm{C}_{2} \mathrm{H}_{4}$, butenes and aromatic hydrocarbons), improve stability and suppress coke formation. Thus, as the yield to $\mathrm{C}_{3} \mathrm{H}_{6}$ rarely exceeds $40.0 \%$, the need for novel catalytic materials is imperative [85].

Other biomass-derived oxygenates, such as polyols, aldehydes, and ketones can also be converted into hydrocarbons through oxygen removal catalytic reactions (hydrogenation/ dehydrogenation, and hydro-deoxygenation). In this context, over transition metal oxides, glycerol and other $C_{3}$ oxygenated compounds can be converted into $\mathrm{C}_{3} \mathrm{H}_{6}$. Glycerol is a low cost molecule that can be produced via fermentation, transesterification and hydrogenolysis reactions, from biomass feedstocks. It can be upgraded into valuable compounds through a number of chemical or biological routes [33]. Glycerol to olefins (GTO) methods require the complete removal of oxygen, which is an intricate task. Its catalytic conversion into $\mathrm{C}_{3} \mathrm{H}_{6}$ is a novel research subject that has recently attracted attention; Hultenberg and Brandin recently filed a patent introducing the production of lower hydrocarbons (e.g., ethane, propane, and propene) from glycerol, over $\mathrm{WO}_{3}$ on $\mathrm{ZrO}_{2}$ and $\mathrm{Pt}$ on $\mathrm{CeO}_{2}$ catalysts. [86] Fadigas et al. initially explored glycerol conversion, in a continuous flow process, over $\mathrm{Ni}$, and $\mathrm{Fe}-\mathrm{Mo}$ metal catalysts supported on activated carbon, obtaining high selectivity values to $\mathrm{C}_{3} \mathrm{H}_{6}$ [87]. Schmidt's group reported glycerol cracking into propanal, acrolein, $\mathrm{C}_{3} \mathrm{H}_{6}$, and $\mathrm{C}_{2} \mathrm{H}_{4}$, in three steps (i.e., dehydration, hydrogenation, and upgrading), over HZSM- 5 zeolites, $\mathrm{Pd} / \alpha-\mathrm{Al}_{2} \mathrm{O}_{3}$, and HBEA zeolites, respectively for each step/reaction [88].

$\mathrm{Yu}$ et al used $\mathrm{Ir} / \mathrm{ZrO}_{2}$ and H-ZSM5 catalysts, in two steps, in order to selectively produce $\mathrm{C}_{3} \mathrm{H}_{6}$ via hydro-deoxygenation in a fixed-dual-bed reactor. Over the optimized reaction conditions (i.e., $250{ }^{\circ} \mathrm{C}$ and 1 bar hydrogen pressure), selectivity to $\mathrm{C}_{3} \mathrm{H}_{6}$ reached $85.0 \%$, for complete glycerol conversion [89]. (Table 3) Sun et al. used $\mathrm{WO}_{3}-\mathrm{Cu} / \mathrm{Al}_{2} \mathrm{O}_{3}$ catalysts, at $250{ }^{\circ} \mathrm{C}$ under hydrogen flow (atmospheric pressure) to obtain $47.4 \%$ selectivity to $\mathrm{C}_{3} \mathrm{H}_{6}$ for $100 \%$ glycerol conversion [91]. Combining $\mathrm{WO}_{3}-\mathrm{Cu} / \mathrm{Al}_{2} \mathrm{O}_{3}$ and $\mathrm{SiO}_{2}-\mathrm{Al}_{2} \mathrm{O}_{3}$ in a dual-bed reactor, selectivity to $\mathrm{C}_{3} \mathrm{H}_{6}$ reached $84.8 \%$. Mota et al, used $\mathrm{Fe} / \mathrm{Mo}$ catalysts supported on activated carbon to obtain 100 glycerol conversion and $90.0 \%$ selectivity to $\mathrm{C}_{3} \mathrm{H}_{6}$ at $300{ }^{\circ} \mathrm{C}$ [92]. In all the above studies, a number of by-products has been detected in the gas phase (e.g., carbon dioxide, propane, and ethylene). Further studies by our group, in a batch reactor, over molybdena-based catalysts supported on carbon, report glycerol production 
into $\mathrm{C}_{3} \mathrm{H}_{6}$ with $100 \%$ selectivity in the gas phase $(88.0 \%$ glycerol conversion and $76.0 \%$ selectivity to $\mathrm{C}_{3} \mathrm{H}_{6}$ ) at $300{ }^{\circ} \mathrm{C}$ and under hydrogen atmosphere ( 80 bar) (Figure 8 ) [90]. Our group has also proven that reducible molybdenum oxides selectively drive this reaction into $\mathrm{C}_{3} \mathrm{H}_{6}$, most probably via a reverse Mars-van Krevelen mechanism; formation of $\mathrm{Mo}^{4+}$ and $\mathrm{Mo}^{5+}$ species most likely drives the reaction to the formation of the desired product. $\mathrm{C}_{3} \mathrm{H}_{6}$ is most probably formed via two consecutive cycles, in a one-step reaction: (a) due to the presence of oxygen vacancies, the adsorption of glycerol proceeds with the two adjacent hydroxyls forming an unstable cyclic intermediate which in turn is released as 2-propenol and (b) the latter after re-adsorption with the remaining hydroxyl is further deoxygenated to $\mathrm{C}_{3} \mathrm{H}_{6}$ [93]. Dow Global Technologies have patented a GTO process in a batch reactor, reaching $96 \%$ selectivity to $\mathrm{C}_{3} \mathrm{H}_{6}$ for $24 \%$ glycerol conversion. Hydroiodic acid acts as a catalyst in subsequent reduction-oxidation cycles, over reductive atmosphere [92].

Table 3. Selected catalysts for one-step glycerol conversion into $\mathrm{C}_{3} \mathrm{H}_{6}$.

\begin{tabular}{cccccc}
\hline Catalyst & $\begin{array}{c}\text { Glycerol } \\
\text { Conversion (\%) }\end{array}$ & $\begin{array}{c}\text { Selectivity to } \\
\mathbf{C}_{\mathbf{3}} \mathbf{H}_{\mathbf{6}} \mathbf{( \% )}\end{array}$ & Temperature $\left({ }^{\circ} \mathbf{C}\right)$ & WHSV $\left(\mathbf{h}^{-\mathbf{1}}\right)$ & Reference \\
\hline $\mathrm{Ir} / \mathrm{ZrO}{ }_{2} \& \mathrm{HZSM}-5-30$ & 100.0 & 85.0 & 250 & 1.0 & {$[89]$} \\
$\mathrm{Fe}-\mathrm{Mo}_{\mathrm{Black} \text { Carbon }}$ & 88.0 & 76.0 & 300 & - & {$[90]$} \\
$\mathrm{WO}_{3}-\mathrm{Cu} / \mathrm{Al}_{2} \mathrm{O}_{3} \& \mathrm{SiO}_{2}-\mathrm{Al}_{2} \mathrm{O}_{3}$ & 100.0 & 84.8 & 250 & - & {$[91]$} \\
$\mathrm{Fe} / \mathrm{Mo}$ & 100.0 & 90.0 & 300 & 5.4 & {$[92]$} \\
\hline
\end{tabular}

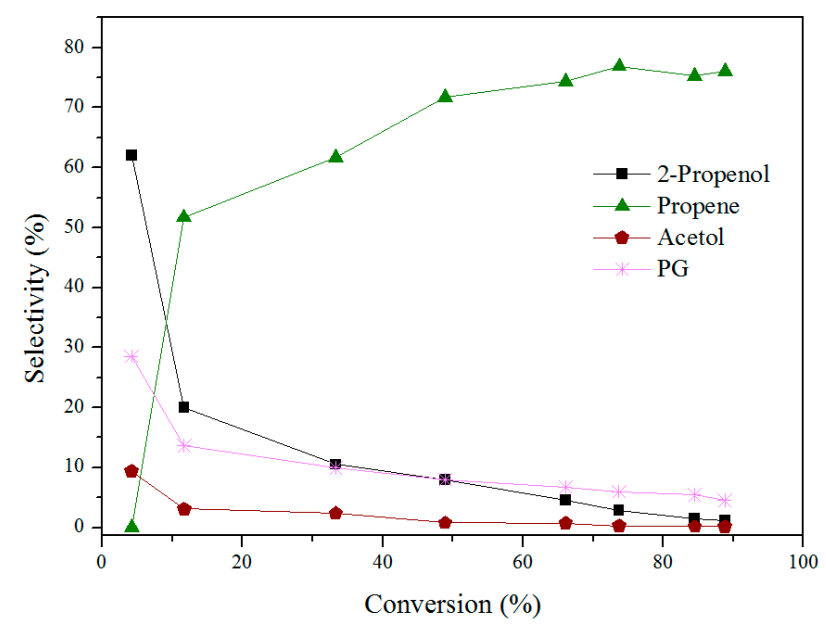

Figure 8. Effect of reaction time on selectivity over the Fe-Mo/BC_A catalyst $\left(\mathrm{H}_{2}\right.$ pressure: $8.0 \mathrm{MPa}$, temperature: $300^{\circ} \mathrm{C}$ ). Reproduced from [90]. Copyright 2015, Royal Society of Chemistry.

Bio-oil, produced from catalytic pyrolysis of fats, oils and other low-values compounds, can also be used as a feedstock for the production of olefins, through processes that are already used in the petrochemicals' industry [94]. Syntroleum Corporation has already implemented similar processed (i.e., Bio-Synfining), where vegetable oils and fats can be converted into fuels and propane [95]. Neste Oil is also using the NExBTL (Next Generation Biomass to Liquid) process in order to produce liquid fuels and olefins [96]. Through steam cracking and fluid catalytic cracking, liquid fuels and $\mathrm{C}_{3} \mathrm{H}_{6}$ can be formed, while via the first route olefins are primarily produced [97]. The first step of the steam cracking process is hydro-deoxygenation of fatty acids and triglycerides, resulting in green hydrocarbons and naphtha. Hydro-deoxygenation proceeds over conventional hydrotreating catalysts, under high hydrogen pressure and moderate temperatures (i.e., 280-400 ${ }^{\circ} \mathrm{C}$ ) [98]. Noble metal catalysts have also been used, supported on carbon, silica, alumina, or zeolites [99]. The second step involves gasoline and $\mathrm{C}_{3} \mathrm{H}_{6}$ production via cracking at atmospheric pressure, at $800{ }^{\circ} \mathrm{C}$. Milder reaction conditions enhance $\mathrm{C}_{3} \mathrm{H}_{6}$ formation, while suppressing $\mathrm{C}_{2} \mathrm{H}_{4}$ and aromatics production. 
Table 4 summarizes the main characteristics of the most important $\mathrm{C}_{3} \mathrm{H}_{6}$ production methods. Through steam cracking $\mathrm{C}_{3} \mathrm{H}_{6}$ can be formed as a by-product of $\mathrm{C}_{2} \mathrm{H}_{4}$ production, at high temperatures, in a markedly energy intense process. Lower temperatures of FCC make this process more environmentally friendly, compared to steam cracking. However, yield to $\mathrm{C}_{3} \mathrm{H}_{6}$ is highly dependent on the feedstock and on the selected condition. Catalyst deactivation and product recovery are among the disadvantages of this rather popular method. Propane dehydrogenation is another $\mathrm{C}_{3} \mathrm{H}_{6}$ production process from finite resources that also requires high temperatures and atmospheric pressure. Recently installed units highlight the potential of this application for on-purpose $\mathrm{C}_{3} \mathrm{H}_{6}$ production at high yields. Via metathesis reactions olefins can be converted into $\mathrm{C}_{3} \mathrm{H}_{6}$, at relatively low temperatures and moderate pressure. Bio-olefins are the most suitable feedstock but their availability limits the productivity of this method. Glycerol to olefins is a novel research subject that aims at the production of "green" $\mathrm{C}_{3} \mathrm{H}_{6}$ through catalytic reactions, at moderate temperature. Nonetheless, more in-depth research is essential on the most suitable catalysts that will selectively drive the reaction. Even though $\mathrm{C}_{3} \mathrm{H}_{6}$ production from glycerol is still a lab-scale application, future studies focusing on scale-up and techno-economic analyses will enable industrial application of these biomass-valorization processes.

Table 4. Comparison of $\mathrm{C}_{3} \mathrm{H}_{6}$ production processes.

\begin{tabular}{|c|c|c|c|c|c|}
\hline Process & Steam Cracking & FCC & Dehydrogenation & Metathesis & GTO \\
\hline Feedstock & $\mathrm{HC}$ & $\mathrm{HC}$ & Propane & Bio-olefins & Glycerol \\
\hline $\begin{array}{l}\text { Operating } \\
\text { Conditions }\end{array}$ & $\begin{array}{c}750-900{ }^{\circ} \mathrm{C} \\
\text { moderate pressure }\end{array}$ & $\begin{array}{c}500-550{ }^{\circ} \mathrm{C} \\
\text { moderate pressure }\end{array}$ & $\begin{array}{c}500-700{ }^{\circ} \mathrm{C} \\
\text { atmospheric pressure }\end{array}$ & $\begin{array}{c}0-260^{\circ} \mathrm{C}, \\
\text { moderate pressure }\end{array}$ & $\begin{array}{c}250-400{ }^{\circ} \mathrm{C}, \\
\text { hydrogen pressure }\end{array}$ \\
\hline Advantages & $\begin{array}{l}\text { Already installed } \\
\text { technology }\end{array}$ & $\begin{array}{l}\text { Greener than } \\
\text { Steam Cracking, } \\
\text { Flexibility of } \\
\text { operation }\end{array}$ & $\begin{array}{c}\text { Already installed } \\
\text { units }\end{array}$ & $\begin{array}{c}\text { Already installed } \\
\text { units }\end{array}$ & $\begin{array}{l}\text { Sustainable } \\
\text { production }\end{array}$ \\
\hline Disadvantages & $\begin{array}{l}\text { Energy intense, } \\
\text { environmental } \\
\text { concerns, finite } \\
\text { resources }\end{array}$ & $\begin{array}{l}\text { Yield depends on } \\
\text { feedstock, catalyst } \\
\text { deactivation, } \\
\text { product recovery }\end{array}$ & $\begin{array}{l}\text { Catalyst deactivation, } \\
\text { endothermic reaction }\end{array}$ & $\begin{array}{l}\text { Limited production } \\
\text { of bio-feedstocks }\end{array}$ & $\begin{array}{c}\text { Require hydrogen } \\
\text { atmosphere, } \\
\text { lab-scale }\end{array}$ \\
\hline Yield to $\mathrm{C}_{3} \mathrm{H}_{6}$ & $18.0 \%$ & $25.0 \%$ & $85.0 \%$ & $90.0 \%$ & $90.0 \%$ \\
\hline
\end{tabular}

\subsection{Butadiene $\left(\mathrm{C}_{4} \mathrm{H}_{6}\right)$}

Alternative feedstocks have been proposed in order to effectively produce bio-butadiene from renewable resources, thus substituting the energy consuming processes of naphtha cracking. In Figure 9, the various production processes for $\mathrm{C}_{4} \mathrm{H}_{6}$ are summarized.

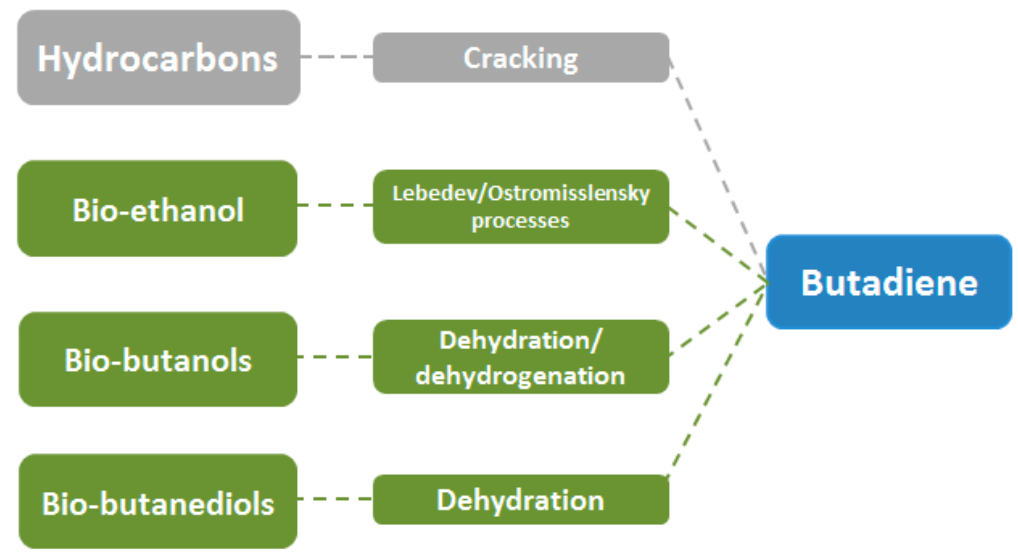

Figure 9. Schematic chart of $\mathrm{C}_{4} \mathrm{H}_{6}$ production methods. 
$\mathrm{C}_{4} \mathrm{H}_{6}$ is also a by-product of $\mathrm{C}_{2} \mathrm{H}_{4}$ production through cracking of hydrocarbons. $\mathrm{C}_{4} \mathrm{H}_{6}$ production from bio-ethanol is a promising alternative that has been industrially implemented prior to the installation of naphtha cracking technologies; ethanol to $\mathrm{C}_{4} \mathrm{H}_{6}$ processes have been used since 1920, constituting the main production practice until the end of World War II [22,100]. Main routes of this process include dehydrogenation, dehydration, and condensation over suitable catalysts, either in one-step (i.e., Lebedev approach) (Scheme 5) or two-step processes (i.e., Ostromisslenski approach) (Scheme 6) [100]. In the first case, multifunctional catalysts have been employed, mainly alumina and magnesia-silica catalysts, via $\mathrm{C}_{2} \mathrm{H}_{4}$ dimerization and subsequent metathesis, while at the latter, ethanol was initially dehydrogenated into acetaldehyde, over copper-based catalysts, at moderate temperatures, and then ethanol reacted with acetaldehyde to form $\mathrm{C}_{4} \mathrm{H}_{6}$, over $\mathrm{Ta}_{2} \mathrm{O}_{5}$ catalyst, as well as other oxides, supported on silica [101,102]. Several research projects suggest that aldol condensation of acetaldehyde is a key step in ethanol conversion into $\mathrm{C}_{4} \mathrm{H}_{6}$ [103]. On the other hand, latest works, including DRIFTS (Diffuse Reflection Infrared Spectroscopy) analyses and DFT (Density Functional Theory) calculations, propose that ethanol carbanionic intermediates are of key importance for the reaction mechanism [104].

$$
2 \mathrm{C}_{2} \mathrm{H}_{6} \mathrm{O} \longrightarrow \mathrm{C}_{4} \mathrm{H}_{6}+2 \mathrm{H}_{2} \mathrm{O}+\mathrm{H}_{2}
$$

Scheme 5. $\mathrm{C}_{4} \mathrm{H}_{6}$ production through the Lebedev process.

$$
\text { 1. } \mathrm{C}_{2} \mathrm{H}_{6} \mathrm{O} \longrightarrow \mathrm{C}_{2} \mathrm{H}_{4} \mathrm{O}+\mathrm{H}_{2}
$$

\section{2. $\mathrm{C}_{2} \mathrm{H}_{6} \mathrm{O}+\mathrm{C}_{2} \mathrm{H}_{4} \mathrm{O} \longrightarrow \mathrm{C}_{4} \mathrm{H}_{6}+2 \mathrm{H}_{2} \mathrm{O}$}

Scheme 6. $\mathrm{C}_{4} \mathrm{H}_{6}$ production through the Ostromisslenski process.

Apart from bio-ethanol, $\mathrm{C}_{4} \mathrm{H}_{6}$ can be formed from other biomass derived oxygenates such as butanols and butanediols, produced through biomass fermentation or gasification [105,106]. In fact, bio-1,4-butanediol is currently produced by Genomatica, at a small scale plant, planning on installing an industrial scale one with Novamont [107]. Acid catalyzed dehydration of bio-butanols yields a mixture of n-butenes. Subsequent dehydrogenation results in the production of $\mathrm{C}_{4} \mathrm{H}_{6}$. N-butanol can be converted into 1-butene or nonlinear $\mathrm{C}_{4}$ olefins, via dehydration, over catalysts with mild or high acidity, respectively; over zeolites a $\sim 60 \%$ yield to isobutene has been obtained [108]. The overwhelming cost of the butene dehydrogenation step has led to research on direct dehydration of butanediols to $\mathrm{C}_{4} \mathrm{H}_{6}$, over suitable catalysts; over sodium phosphate catalysts, 1,4-butanediol can be converted into $\mathrm{C}_{4} \mathrm{H}_{6}$ at $280{ }^{\circ} \mathrm{C}$, while conversion of 1,3-butanediol requires higher temperatures, over the same catalysts [109]. $\mathrm{C}_{4} \mathrm{H}_{6}$ yield up to $95 \%$ has been reported from 1,4-butanediol [110] and $90 \%$ from 1,3-butanediol [103]. In both cases, increased by-product formation is a critical issue that further studies on catalytic approaches could address. Dehydration of other $\mathrm{C}_{4}$ diols (e.g., 2,3-butanediol) is much more challenging, requiring multiple and more complex reaction steps [111]. 2,3-butanediol, produced via glucose fermentation, can be converted into $\mathrm{C}_{4} \mathrm{H}_{6}$, over scandium oxide catalysts, at high temperatures (i.e., $411^{\circ} \mathrm{C}$ ), reaching $88 \%$ yield. Using two catalytic beds, with scandium oxide and alumina, selectivity to $\mathrm{C}_{4} \mathrm{H}_{6}$ was $94 \%$, proving the feasibility of direct double bond dehydration of 2,3-butanediol [91]. Alternatively, two-step processes, using two different catalysts (e.g., silica or alumina-based) for subsequent dehydrations, have also been proposed, yielding $\mathrm{C}_{4} \mathrm{H}_{6}$ via the formation of unsaturated alcohols [112]. Novel chemical and biochemical technologies enable the production of $\mathrm{C}_{4} \mathrm{H}_{6}$ from syngas originating from the gasification of biomass or waste gases from the steel industry; butanediols can be produced from syngas via fermentation [113]. As syngas can be produced from various organic materials, such as biomass, it is rather inexpensive. Thus, it is an excellent resource for the production of valuable bio-chemicals and bio-fuels [114]. Bio-catalytic 
processes enable syngas fermentation in moderate conditions, increasing energy saving, improving product yield and involving less toxic compounds or products $[115,116]$. Despite the fact that syngas fermentation is still an immature approach, its future potential cannot be ignored.

As lighter olefins are most preferably produced via steam cracking, $\mathrm{C}_{4} \mathrm{H}_{6}$ production is rather limited through this process. Via dehydrogenation, butane-or butenes via oxidative dehydrogenation, can be selectively converted into $\mathrm{C}_{4} \mathrm{H}_{6}$ but the high temperatures and catalyst deactivation are key disadvantages impeding commercialization. Bio-ethanol conversion into $\mathrm{C}_{4} \mathrm{H}_{6}$ is the most promising alternative; numerous studies have focused on the selection of the most suitable catalyst. However, catalytic deactivation and increased by-product formation are still critical issues that further research could resolve. Via dehydration/hydrogenation steps, bio-butanol can be effectively converted into $\mathrm{C}_{4} \mathrm{H}_{6}$, but the limited availability of the feedstock, along with the significantly high cost due to high temperature (up to $700{ }^{\circ} \mathrm{C}$ ) and to the hydrogenation step, hinder industrial application. (Table 5) On the other hand, relatively lower temperatures of highly selective bio-butanediol dehydration could enable its applicability, even though production of the bio-feedstock is quite limited and by-product formation is not negligible. To conclude, all bio-based methods for $\mathrm{C}_{4} \mathrm{H}_{6}$ production are still in lab-scale. Nonetheless, in the future, novel catalysts can be synthesized for the selective $\mathrm{C}_{4} \mathrm{H}_{6}$ production. Moreover, further studies on production of the biomass-derived feedstocks could reduce the cost and increase their availability in order to facilitate the implementation of these processes.

Table 5. Comparison of $\mathrm{C}_{4} \mathrm{H}_{6}$ production processes.

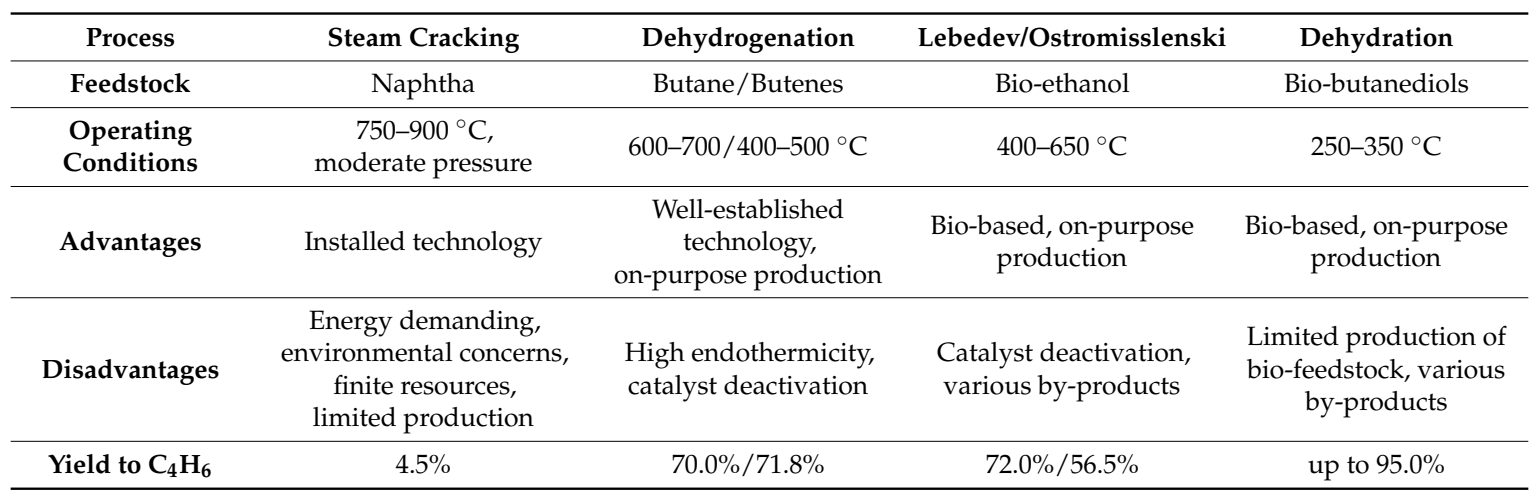

\section{Concluding Remarks}

Production of bio-olefins is a broad research field that is continuously expanding, as the demand is incessantly increasing, worldwide. Biomass derived intermediates offer numerous opportunities for alternative reaction pathways, yielding ethylene, propylene, or butadiene, in less energy demanding and cost effective processes that do not exploit the finite fossil resources. Bio-olefins can be produced via numerous processes, some of which have already been implemented in industrial applications.

Ethanol dehydration is the most promising bio-based process for bio-ethylene production that has already been installed, operating at relatively moderate temperatures. MTO and DMTO are close to commercial application, using bio-methanol and bio-DME as feedstocks, for selective ethylene production. In all cases, limited bio-ethanol supply is a key drawback that affects possibility of industrial applications. Bio-synthesis is an interesting research subject on selective sustainable production, but more in-depth studies are essential in order to increase productivity and significantly lower the cost.

Bio-propylene can be effectively produced through bio-olefin metathesis and glycerol to olefins methods, operating at relatively moderate conditions with increased bio-propylene yields. In fact, olefin metathesis technology has already been implemented; however, limited bio-feedstock availability strongly affects productivity and viability of this process. GTO methods include a wide range of processes that could yield bio-propylene in lab-scale applications. Nevertheless, studies on the most 
efficient and stable catalyst that will lower hydrogen demand are expected to make these processes applicable in the near future.

Bio-butadiene can be primarily produced from bio-ethanol via the Lebedev/Ostromisslenski methods that have been extensively studied in the past decades. Dehydration of bio-butanediols is the most promising approach, reaching $95 \%$ yield to butadiene, at lower temperature than the other alternatives. Bio-butanol can also be used as a feedstock for bio-butadiene production, but the high operation cost due to hydrogenation step and high temperature limits feasibility of implementation. Additionally, $\mathrm{C}_{4}$ bio-feedstock production is also limited in order to ensure future viable industrial applications.

Overall, several bio-based processes have been proposed with high potential in bio-olefin yields. Even though the majority of them are still in laboratory scale, a few have already been implemented around the world. The main drawback in the scale-up of these processes is the availability of the bio-feedstocks which can be produced from various biomass derivatives via fermentation, bio-synthesis, cracking, and deoxygenation among others. Future studies should mainly focus on increasing the productivity of these methods, along with reducing the cost, in order to facilitate their implementation in bio-olefin production units. In most catalytic approaches, novel low-cost catalytic systems with improved properties regarding selectivity and reaction conditions should also be researched to advance future applications.

Acknowledgments: This research has been financed by the State Scholarships Foundation (IKY) through the program "RESEARCH PROJECTS FOR EXCELLENCE IKY/SIEMENS".

Conflicts of Interest: The authors declare no conflict of interest.

\section{References}

1. BP. Statistical Review of World Energy; BP: London, UK, 2017.

2. Amghizar, I.; Vandewalle, L.A.; Van Geem, K.M.; Marin, G.B. New Trends in Olefin Production. Engineering 2017, 3, 171-178. [CrossRef]

3. Bender, M. An Overview of Industrial Processes for the Production of Olefins-C4 Hydrocarbons. ChemBioEng Rev. 2014, 1, 136-147. [CrossRef]

4. Torres Galvis, H.M.; de Jong, K.P. Catalysts for Production of Lower Olefins from Synthesis Gas: A Review. ACS Catal. 2013, 3, 2130-2149. [CrossRef]

5. Matar, S.; Hatch, L.F. Chemistry of Petrochemical Processes; Gulf Professional Publishing: Houston, TX, USA, 2009.

6. Weissermel, K.; Arpe, H. Oxidation Products Ethylene. In Industrial Organic Chemistry; Wiley-VCH Verlag GmbH: Weinheim, Germany, 1978; pp. 145-192; ISBN 9783527619191.

7. Zimmermann, H.; Walzl, R. Ethylene. In Ullmann's Encyclopedia of Industrial Chemistry; Wiley-VCH Verlag GmbH \& Co. KGaA: Weinheim, Germany, 2009; ISBN 9783527306732.

8. Mohsenzadeh, A.; Zamani, A.; Taherzadeh, M.J. Bioethylene Production from Ethanol: A Review and Techno-economical Evaluation. ChemBioEng Rev. 2017, 4, 75-91. [CrossRef]

9. Chang, C.D. Methanol Conversion to Light Olefins. Catal. Rev. 1984, 26, 323-345. [CrossRef]

10. Haro, P.; Trippe, F.; Stahl, R.; Henrich, E. Bio-syngas to gasoline and olefins via DME-A comprehensive techno-economic assessment. Appl. Energy 2013, 108, 54-65. [CrossRef]

11. McManus, M.T. The Plant Hormone Ethylene; Wiley-Blackwell: Hoboken, NJ, USA, 2012; ISBN 1444330039.

12. Ding, J.; Hua, W. Game Changers of the C3 Value Chain: Gas, Coal, and Biotechnologies. Chem. Eng. Technol. 2013, 36, 83-90. [CrossRef]

13. Eisele, P.; Killpack, R. Propene. In Ullmann's Encyclopedia of Industrial Chemistry; Wiley-VCH Verlag GmbH \& Co. KGaA: Weinheim, Germany, 2011; ISBN 9783527306732.

14. Sahebdelfar, S.; Zangeneh, F.T. Dehydrogenation of Propane to Propylene Over Pt-Sn $/ \mathrm{Al}_{2} \mathrm{O}_{3}$ Catalysts: The influence of operating conditions on product selectivity. Iran. J. Chem. Eng. 2010, 7, 51-57.

15. Lwin, S.; Wachs, I.E. Olefin Metathesis by Supported Metal Oxide Catalysts. ACS Catal. 2014, 4, 2505-2520. [CrossRef] 
16. Chen, D.; Moljord, K.; Holmen, A. A methanol to olefins review: Diffusion, coke formation and deactivation on SAPO type catalysts. Microporous Mesoporous Mater. 2012, 164, 239-250. [CrossRef]

17. Tian, P.; Wei, Y.; Ye, M.; Liu, Z. Methanol to Olefins (MTO): From Fundamentals to Commercialization. ACS Catal. 2015, 5, 1922-1938. [CrossRef]

18. Werpy, T.; Petersen, G.; Aden, A.; Bozell, J. Top Value Added Chemicals from Biomass. Volume 1-Results of Screening for Potential Candidates from Sugars and Synthesis Gas; U.S. Department of Energy: Washington, DC, USA, 2004.

19. Bruijnincx, P.C.A.; Weckhuysen, B.M. Shale Gas Revolution: An Opportunity for the Production of Biobased Chemicals? Angew. Chem. Int. Ed. 2013, 52, 11980-11987. [CrossRef] [PubMed]

20. Siirola, J.J. The impact of shale gas in the chemical industry. AIChE J. 2014, 60, 810-819. [CrossRef]

21. Fiorentino, G.; Ripa, M.; Ulgiati, S. Chemicals from biomass: Technological versus environmental feasibility. A review. Biofuels Bioprod. Biorefin. 2017, 11, 195-214. [CrossRef]

22. Chieregato, A.; Ochoa, J.V.; Cavani, F. Olefins from Biomass. In Chemicals and Fuels from Bio-Based Building Blocks; Cavani, F., Albonetti, S., Basile, F., Gandini, A., Eds.; Wiley-VCH Verlag GmbH \& Co. KGaA: Weinheim, Germany, 2016. [CrossRef]

23. Yang, S.F.; Hoffman, N.E. Ethylene Biosynthesis and its Regulation in Higher Plants. Annu. Rev. Plant Physiol. 1984, 35, 155-189. [CrossRef]

24. Lynch, S.; Eckert, C.; Yu, J.; Gill, R.; Maness, P.-C. Overcoming substrate limitations for improved production of ethylene in E. coli. Biotechnol. Biofuels 2016, 9, 3. [CrossRef] [PubMed]

25. Nickerson, W.J. Ethylene as a metabolic product of the pathogenic fungus, Blastomyces dermatitidis. Arch Biochem. 1948, 17, 225-233. [PubMed]

26. Eckert, C.; Xu, W.; Xiong, W.; Lynch, S.; Ungerer, J.; Tao, L.; Gill, R.; Maness, P.-C.; Yu, J. Ethylene-forming enzyme and bioethylene production. Biotechnol. Biofuels 2014, 7, 33. [CrossRef] [PubMed]

27. Wang, J.P.; Wu, L.X.; Xu, F.; Lv, J.; Jin, H.J.; Chen, S.F. Metabolic engineering for ethylene production by inserting the ethylene-forming enzyme gene (efe) at the $16 \mathrm{~S}$ rDNA sites of Pseudomonas putida KT2440. Bioresour. Technol. 2010, 101, 6404-6409. [CrossRef] [PubMed]

28. Markham, J.N.; Tao, L.; Davis, R.; Voulis, N.; Angenent, L.T.; Ungerer, J.; Yu, J. Techno-economic analysis of a conceptual biofuel production process from bioethylene produced by photosynthetic recombinant cyanobacteria. Green Chem. 2016, 18, 6266-6281. [CrossRef]

29. Zhang, M.; Yu, Y. Dehydration of ethanol to ethylene. Ind. Eng. Chem. Res. 2013, 52, 9505-9514. [CrossRef]

30. Fan, D.; Dai, D.J.; Wu, H.S. Ethylene formation by catalytic dehydration of ethanol with industrial considerations. Materials 2013, 6, 101-115. [CrossRef] [PubMed]

31. Kosaric, N.; Duvnjak, Z.; Farkas, A.; Sahm, H.; Bringer-Meyer, S.; Goebel, O.; Mayer, D.; Kosaric, N.; Duvnjak, Z.; Farkas, A.; et al. Ethanol. In Ullmann's Encyclopedia of Industrial Chemistry; Wiley-VCH Verlag GmbH \& Co. KGaA: Weinheim, Germany, 2011; pp. 1-72; ISBN 9783527306732.

32. Althoff, J.; Biesheuvel, K.; De Kok, A.; Pelt, H.; Ruitenbeek, M.; Spork, G.; Tange, J.; Wevers, R. Economic Feasibility of the Sugar Beet-to-Ethylene Value Chain. ChemSusChem 2013, 6, 1625-1630. [CrossRef] [PubMed]

33. Sheldon, R.A. Green and sustainable manufacture of chemicals from biomass: State of the art. Green Chem. 2014, 16, 950-963. [CrossRef]

34. Fukumoto, M.; Kimura, A. Process for the Manufacture of Ethylene by Dehydration of Ethanol. EP 2594546 A1, 17 November 2011.

35. Chen, Y.; Wu, Y.; Tao, L.; Dai, B.; Yang, M.; Chen, Z.; Zhu, X. Dehydration reaction of bio-ethanol to ethylene over modified SAPO catalysts. J. Ind. Eng. Chem. 2010, 16, 717-722. [CrossRef]

36. Wu, L.; Shi, X.; Cui, Q.; Wang, H.; Huang, H. Effects of the SAPO-11 synthetic process on dehydration Of ethanol to ethylene. Front. Chem. Sci. Eng. 2011, 5, 60-66. [CrossRef]

37. Zhang, D.; Wang, R.; Yang, X. Effect of P content on the catalytic performance of P-modified HZSM-5 catalysts in dehydration of ethanol to ethylene. Catal. Lett. 2008, 124, 384-391. [CrossRef]

38. Patrick, G.B.; Partington, S.R. Process for Preparing Ethene. U.S. Patent 8822748 B2, 8 October 2008.

39. Lanzafame, P.; Centi, G.; Perathoner, S. Evolving scenarios for biorefineries and the impact on catalysis. Catal. Today 2014, 234, 2-12. [CrossRef]

40. Kang, M.; DeWilde, J.F.; Bhan, A. Kinetics and Mechanism of Alcohol Dehydration on $\gamma-\mathrm{Al}_{2} \mathrm{O}_{3}$ : Effects of Carbon Chain Length and Substitution. ACS Catal. 2015, 5, 602-612. [CrossRef] 
41. Christiansen, M.A.; Mpourmpakis, G.; Vlachos, D.G. DFT-driven multi-site microkinetic modeling of ethanol conversion to ethylene and diethyl ether on $\gamma-\mathrm{Al}_{2} \mathrm{O}_{3}$ (1 1 1). J. Catal. 2015, 323, 121-131. [CrossRef]

42. Potter, M.E.; Cholerton, M.E.; Kezina, J.; Bounds, R.; Carravetta, M.; Manzoli, M.; Gianotti, E.; Lefenfeld, M.; Raja, R. Role of Isolated Acid Sites and Influence of Pore Diameter in the Low-Temperature Dehydration of Ethanol. ACS Catal. 2014, 4, 4161-4169. [CrossRef]

43. DeWilde, J.F.; Czopinski, C.J.; Bhan, A. Ethanol Dehydration and Dehydrogenation on $\gamma-\mathrm{Al}_{2} \mathrm{O}_{3}$ : Mechanism of Acetaldehyde Formation. ACS Catal. 2014, 4, 4425-4433. [CrossRef]

44. Kochar, N.K.; Merims, R.; Padia, A.S. Ethylene from Ethanol. Chem. Eng. Prog. 1981, 6, 66-70.

45. Ondrey, G. The Launch of a New Bioethylene-Production Process; Chemical Engineering: New York, NY, USA, 2014.

46. Chen, G.; Li, S.; Jiao, F.; Yuan, Q. Catalytic dehydration of bioethanol to ethylene over $\mathrm{TiO}_{2} / \gamma-\mathrm{Al}_{2} \mathrm{O}_{3}$ catalysts in microchannel reactors. Catal. Today 2007, 125, 111-119. [CrossRef]

47. Zhan, N.; Hu, Y.; Li, H.; Yu, D.; Han, Y.; Huang, H. Lanthanum-phosphorous modified HZSM-5 catalysts in dehydration of ethanol to ethylene: A comparative analysis. Catal. Commun. 2010, 11, 633-637. [CrossRef]

48. Ciftci, A.; Varisli, D.; Tokay, K.C.; Sezgi, N.A.; Dogu, T. Dimethyl ether, diethyl ether \& ethylene from alcohols over tungstophosphoric acid based mesoporous catalysts. Chem. Eng. J. 2012, 207-208, 85-93.

49. Varisli, D.; Dogu, T.; Dogu, G. Silicotungstic acid impregnated MCM-41-like mesoporous solid acid catalysts for dehydration of ethanol. Ind. Eng. Chem. Res. 2008, 47, 4071-4076. [CrossRef]

50. Chang, C.D.; Silvestri, A.J. The conversion of methanol and other O-compounds to hydrocarbons over zeolite catalysts. J. Catal. 1977, 47, 249-259. [CrossRef]

51. Olsbye, U.; Svelle, S.; Bjorgen, M.; Beato, P.; Janssens, T.V.W.; Joensen, F.; Bordiga, S.; Lillerud, K.P. Conversion of methanol to hydrocarbons: How zeolite cavity and pore size controls product selectivity. Angew. Chem. Int. Ed. 2012, 51, 5810-5831. [CrossRef] [PubMed]

52. Güllü, D.; Demirbas, A. Biomass to methanol via pyrolysis process. Energy Convers. Manag. 2001, 42, 1349-1356. [CrossRef]

53. Liu, Z.; Liang, J. Methanol to olefins conversion catalysts Curr. Opin. Solid State Mater. Sci. 1999, 4, 80-84. [CrossRef]

54. Galindo, C.P.; Badr, O. Renewable hydrogen utilisation for the production of methanol. Energy Convers. Manag. 2007, 48, 519-527. [CrossRef]

55. Taylor, C.E.; Noceti, R.P.; Joseph, R.D. New developments in the photocatalytic conversion of methane to methanol. Catal. Today 2000, 55, 259-267. [CrossRef]

56. Shamsul, N.S.; Kamarudin, S.K.; Rahman, N.A.; Kofli, N.T. An overview on the production of bio-methanol as potential renewable energy. Renew. Sustain. Energy Rev. 2014, 33, 578-588. [CrossRef]

57. Liang, J.; Li, H.; Zhao, S.; Guo, W.; Wang, R.; Ying, M. Characteristics and performance of SAPO-34 catalyst for methanol-to-olefin conversion. Appl. Catal. 1990, 64, 31-40. [CrossRef]

58. Raffelt, K.; Henrich, E.; Koegel, A.; Stahl, R.; Steinhardt, J.; Weirich, F. The BTL2 Process of Biomass Utilization Entrained-Flow Gasification of Pyrolyzed Biomass Slurries. Appl. Biochem. Biotechnol. 2006, 129, 153-164. [CrossRef]

59. Henrich, E.; Dahmen, N.; Dinjus, E. Cost estimate for biosynfuel production via biosyncrude gasification. Biofuels Bioprod. Biorefin. 2009, 3, 28-41. [CrossRef]

60. Wright, M.M.; Brown, R.C.; Boateng, A.A. Distributed processing of biomass to bio-oil for subsequent production of Fischer-Tropsch liquids. Biofuels Bioprod. Biorefin. 2008, 2, 229-238. [CrossRef]

61. Kvisle, S.; Fuglerud, T.; Kolboe, S.; Olsbye, U.; Lillerud, K.P.; Vora, B.V.; Kvisle, S.; Fuglerud, T.; Kolboe, S.; Olsbye, U.; et al. Methanol-to-Hydrocarbons. In Handbook of Heterogeneous Catalysis; Wiley-VCH Verlag GmbH \& Co. KGaA: Weinheim, Germany, 2008; ISBN 9783527610044.

62. Ren, T.; Patel, M.; Blok, K. Olefins from conventional and heavy feedstocks: Energy use in steam cracking and alternative processes. Energy 2006, 31, 425-451. [CrossRef]

63. Akah, A.; Al-Ghrami, M. Maximizing propylene production via FCC technology. Appl. Petrochem. Res. 2015, 5, 377-392. [CrossRef]

64. Sattler, J.J.H.B.; Ruiz-Martinez, J.; Santillan-Jimenez, E.; Weckhuysen, B.M. Catalytic Dehydrogenation of Light Alkanes on Metals and Metal Oxides. Chem. Rev. 2014, 114, 10613-10653. [CrossRef] [PubMed]

65. Zhang, S.; Gong, Y.; Zhang, L.; Liu, Y.; Dou, T.; Xu, J.; Deng, F. Hydrothermal treatment on ZSM-5 extrudates catalyst for methanol to propylene reaction: Finely tuning the acidic property. Fuel Process. Technol. 2015, 129, 130-138. [CrossRef] 
66. Banks, R.L.; Kukes, S.G. New developments and concepts in enhancing activities of heterogeneous metathesis catalysts. J. Mol. Catal. 1985, 28, 117-131. [CrossRef]

67. Knifton, J.F.; Sanderson, J.R.; Stockton, M.E. Tert-butanol dehydration to isobutylene via reactive distillation. Catal. Lett. 2001, 73, 55-57. [CrossRef]

68. Kozlowski, J.T.; Davis, R.J. Heterogeneous catalysts for the guerbet coupling of alcohols. ACS Catal. 2013, 3, 1588-1600. [CrossRef]

69. Dowson, G.R.M.; Haddow, M.F.; Lee, J.; Wingad, R.L.; Wass, D.F. Catalytic conversion of ethanol into an advanced biofuel: Unprecedented selectivity for n-butanol. Angew. Chem. Int. Ed. 2013, 52, 9005-9008. [CrossRef] [PubMed]

70. HOOD, A.D., Jr.; Bridges, R.S. Staged Propylene Production Process. WO 2014110125 A1, 17 July 2014.

71. Mol, J.C. Industrial applications of olefin metathesis. J. Mol. Catal. A Chem. 2004, 213, 39-45. [CrossRef]

72. Huang, S.; Liu, S.; Xin, W.; Bai, J.; Xie, S.; Wang, Q.; Xu, L. Metathesis of ethene and 2-butene to propene on $\mathrm{W} / \mathrm{Al}_{2} \mathrm{O}_{3}$-HY catalysts with different HY contents. J. Mol. Catal. A Chem. 2005, 226, 61-68. [CrossRef]

73. Bouchmella, K.; Hubert Mutin, P.; Stoyanova, M.; Poleunis, C.; Eloy, P.; Rodemerck, U.; Gaigneaux, E.M.; Debecker, D.P. Olefin metathesis with mesoporous rhenium-silicium-aluminum mixed oxides obtained via a one-step non-hydrolytic sol-gel route. J. Catal. 2013, 301, 233-241. [CrossRef]

74. Busca, G. Heterogeneous Catalytic Materials: Solid State Chemistry, Surface Chemistry and Catalytic Behaviour; Elsevier: Warsaw, Poland, 2014.

75. Popoff, N.; Mazoyer, E.; Pelletier, J.; Gauvin, R.M.; Taoufik, M. Expanding the scope of metathesis: A survey of polyfunctional, single-site supported tungsten systems for hydrocarbon valorization. Chem. Soc. Rev. 2013, 42, 9035-9054. [CrossRef] [PubMed]

76. Inoue, K.; Inaba, M.; Takahara, I.; Murata, K. Conversion of ethanol to propylene by H-ZSM-5 with Si/ $\mathrm{Al}_{2}$ ratio of 280. Catal. Lett. 2010, 136, 14-19. [CrossRef]

77. Kazuhisa, M.; Takahara, I.; Inaba, M. Propane Formation by Aqueous-Phase Reforming of Glycerol over Pt/H-ZSM5 Catalysts. React. Kinet. Catal. Lett. 2008, 93, 59-66.

78. Lin, B.; Zhang, Q.; Wang, Y. Catalytic conversion of ethylene to propylene and butenes over H-ZSM-5. Ind. Eng. Chem. Res. 2009, 48, 10788-10795. [CrossRef]

79. Huangfu, J.; Mao, D.; Zhai, X.; Guo, Q. Remarkably enhanced stability of HZSM-5 zeolite co-modified with alkaline and phosphorous for the selective conversion of bio-ethanol to propylene. Appl. Catal. A Gen. 2016, 520, 99-104. [CrossRef]

80. Zhang, N.; Mao, D.; Zhai, X. Selective conversion of bio-ethanol to propene over nano-HZSM-5 zeolite: Remarkably enhanced catalytic performance by fluorine modification. Fuel Process. Technol. 2017, 167, 50-60. [CrossRef]

81. Hayashi, F.; Iwamoto, M. Yttrium-modified ceria as a highly durable catalyst for the selective conversion of ethanol to propene and ethene. ACS Catal. 2013, 3, 14-17. [CrossRef]

82. Hayashi, F.; Tanaka, M.; Lin, D.; Iwamoto, M. Surface structure of yttrium-modified ceria catalysts and reaction pathways from ethanol to propene. J. Catal. 2014, 316, 112-120. [CrossRef]

83. Iwamoto, M.; Mizuno, S.; Tanaka, M. Direct and selective production of propene from bio-ethanol on Sc-loaded $\mathrm{In}_{2} \mathrm{O}_{3}$ catalysts. Chem. A Eur. J. 2013, 19, 7214-7220. [CrossRef] [PubMed]

84. Xia, W.; Wang, F.; Mu, X.; Chen, K.; Takahashi, A.; Nakamura, I.; Fujitani, T. Catalytic performance of H-ZSM-5 zeolites for conversion of ethanol or ethylene to propylene: Effect of reaction pressure and $\mathrm{SiO}_{2} / \mathrm{Al}_{2} \mathrm{O}_{3}$ ratio. Catal. Commun. 2017, 91, 62-66. [CrossRef]

85. Xue, F.; Miao, C.; Yue, Y.; Hua, W.; Gao, Z. Direct conversion of bio-ethanol to propylene in high yield over the composite of $\operatorname{In}_{2} \mathrm{O}_{3}$ and zeolite beta. Green Chem. 2017. [CrossRef]

86. Hulteberg, C.; Brandin, J. Process for Preparing Lower Hydrocarbons from Glycerol. U.S. Patent 20110224470 A1, 15 September 2011.

87. Souza, F.J.C.; Gambetta, R.; de Araujo Mota, C.J.; da Conceicao Goncalves, V.L. Preparation of Heterogeneous Catalysts Used in Selective Hydrogenation of Glycerin to Propene, and a Process for the Selective Hydrogenation of Glycerin to Propene. U.S. Patent 8841497 B2, 24 June 2009.

88. Blass, S.D.; Hermann, R.J.; Persson, N.E.; Bhan, A.; Schmidt, L.D. Conversion of glycerol to light olefins and gasoline precursors. Appl. Catal. A Gen. 2014, 475, 10-15. [CrossRef]

89. Yu, L.; Yuan, J.; Zhang, Q.; Liu, Y.M.; He, H.Y.; Fan, K.N.; Cao, Y. Propylene from renewable resources: Catalytic conversion of glycerol into propylene. ChemSusChem 2014, 7, 743-747. [CrossRef] [PubMed] 
90. Zacharopoulou, V.; Vasiliadou, E.S.; Lemonidou, A.A. One-step propylene formation from bio-glycerol over molybdena-based catalysts. Green Chem. 2015, 17, 903-912. [CrossRef]

91. Sun, D.; Yamada, Y.; Sato, S. Efficient production of propylene in the catalytic conversion of glycerol. Appl. Catal. B Environ. 2015, 174, 13-20. [CrossRef]

92. Deshpande, R.; Davis, P.; Pandey, V.; Kore, N. Dehydroxylation of Crude Alcohol Streams Using a Halogen-Based Catalyst. WO 2013090076 A1, 20 June 2013.

93. Zacharopoulou, V.; Vasiliadou, E.; Lemonidou, A.A. Exploring the reaction pathways of bio-glycerol hydro-deoxygenation to propene over Molybdena-based catalysts. ChemSusChem 2017. [CrossRef] [PubMed]

94. Pyl, S.P.; Schietekat, C.M.; Reyniers, M.F.; Abhari, R.; Marin, G.B.; Van Geem, K.M. Biomass to olefins: Cracking of renewable naphtha. Chem. Eng. J. 2011, 176-177, 178-187. [CrossRef]

95. Ramin, A.H.; Lynn Tomlinson, G.R. Biorenewable Naphtha Composition and Methods of Making Same. U.S. Patent 8581013 B2, 12 November 2013.

96. Vermeiren, W.; Van Gyseghem, N. A process for the Production of Bio-Naphtha from Complex Mixtures of Natural Occurring Fats \& Oils. WO 2011012439 A1, 3 February 2011.

97. Bielansky, P.; Weinert, A.; Schönberger, C.; Reichhold, A. Catalytic conversion of vegetable oils in a continuous FCC pilot plant. Fuel Process. Technol. 2011, 92, 2305-2311. [CrossRef]

98. Mortensen, P.M.; Grunwaldt, J.D.; Jensen, P.A.; Knudsen, K.G.; Jensen, A.D. A review of catalytic upgrading of bio-oil to engine fuels. Appl. Catal. A Gen. 2011, 407, 1-19. [CrossRef]

99. Ruddy, D.A.; Schaidle, J.A.; Ferrell, J.R., III; Wang, J.; Moens, L.; Hensley, J.E. Recent advances in heterogeneous catalysts for bio-oil upgrading via "ex situ catalytic fast pyrolysis": Catalyst development through the study of model compounds. Green Chem. 2014, 16, 454-490. [CrossRef]

100. Angelici, C.; Weckhuysen, B.M.; Bruijnincx, P.C.A. Chemocatalytic conversion of ethanol into butadiene and other bulk chemicals. ChemSusChem 2013, 6, 1595-1614. [CrossRef] [PubMed]

101. Quattlebaum, W.M., Jr.; Toussaint, W.J. Process of Making Olefins. U.S. Patent 2407291 A, 10 September 1946.

102. Toussant, W.J.; Dunn, J.T.; Jackson, D.R. Production of Butadiene from Alcohol. Ind. Eng. Chem. 1947, 39, 120-125. [CrossRef]

103. Makshina, E.V.; Dusselier, M.; Janssens, W.; Degrève, J.; Jacobs, P.A.; Sels, B.F. Review of old chemistry and new catalytic advances in the on-purpose synthesis of butadiene. Chem. Soc. Rev. 2014, 43, 7917-7953. [CrossRef] [PubMed]

104. Chieregato, A.; Ochoa, J.V.; Bandinelli, C.; Fornasari, G.; Cavani, F.; Mella, M. On the chemistry of ethanol on basic oxides: Revising mechanisms and intermediates in the lebedev and guerbet reactions. ChemSusChem 2015, 8, 377-388. [CrossRef] [PubMed]

105. Xiu, Z.L.; Zeng, A.P. Present state and perspective of downstream processing of biologically produced 1,3-propanediol and 2,3-butanediol. Appl. Microbiol. Biotechnol. 2008, 78, 917-926. [CrossRef] [PubMed]

106. Celińska, E.; Grajek, W. Biotechnological production of 2,3-butanediol-Current state and prospects. Biotechnol. Adv. 2009, 27, 715-725. [CrossRef] [PubMed]

107. Mark, J.B.; Anthony, P.B.; Robin, E.O.; Jun, S.P.P. Microorganisms for Producing Butadiene and Methods Related Thereto. WO 2012177710 A1, 27 December 2012.

108. Zhang, D.; Barri, S.A.I.; Chadwick, D. N-Butanol to iso-butene in one-step over zeolite catalysts. Appl. Catal. A Gen. 2011, 403, 1-11. [CrossRef]

109. Arpe, H.-J.; Weissermel, K. Industrial Organic Chemistry; Wiley-VCH: Weinheim, Germany, 2010; ISBN 3527320024.

110. Reppe, W.; Steinhofer, A.; Daumiller, G. Verfahren zur Herstellung von Diolefinen. DE 899350, 10 August 1953.

111. Kopke, M.; Mihalcea, C.; Liew, F.; Tizard, J.H.; Ali, M.S.; Conolly, J.J.; Al-Sinawi, B.; Simpson, S.D. 2,3-Butanediol Production by Acetogenic Bacteria, an Alternative Route to Chemical Synthesis, Using Industrial Waste Gas. Appl. Environ. Microbiol. 2011, 77, 5467-5475. [CrossRef] [PubMed]

112. Duan, H.; Yamada, Y.; Sato, S. Selective dehydration of 2,3-butanediol to 3-buten-2-ol over $\mathrm{ZrO}_{2}$ modified with CaO. Appl. Catal. A Gen. 2014, 487, 226-233. [CrossRef]

113. Mohammadi, M.; Najafpour, G.D.; Younesi, H.; Lahijani, P.; Uzir, M.H.; Mohamed, A.R. Bioconversion of synthesis gas to second generation biofuels: A review. Renew. Sustain. Energy Rev. 2011, 15, 4255-4273. [CrossRef] 
114. Choi, D.W.; Chipman, D.C.; Bents, S.C.; Brown, R.C. A techno-economic analysis of polyhydroxyalkanoate and hydrogen production from syngas fermentation of gasified biomass. Appl. Biochem. Biotechnol. 2010, 160, 1032-1046. [CrossRef] [PubMed]

115. Bredwell, M.D.; Srivastava, P.; Worden, R.M. Reactor Design Issues for Synthesis-Gas Fermentations. Biotechnol. Prog. 1999, 15, 834-844. [CrossRef] [PubMed]

116. Madhukar, G.R.; Elmore, B.B.; Huckabay, H.K. Microbial conversion of synthesis gas components to useful fuels and chemicals, Microbial Conversion of Synthesis Gas Components to Useful Fuels and Chemicals Symposium. In Seventeenth Symposium on Biotechnology for Fuels and Chemicals; Wyman, C.E., Davison, B.H., Eds.; ABAB Symposium, Volume 57/58; Humana Press: Totowa, NJ, USA, 1996.

(C) 2017 by the authors. Licensee MDPI, Basel, Switzerland. This article is an open access article distributed under the terms and conditions of the Creative Commons Attribution (CC BY) license (http://creativecommons.org/licenses/by/4.0/). 